\title{
Chemical Composition and Antimicrobial Potential of Palm Leaf Extracts from Babaçu (Attalea speciosa), Buriti (Mauritia flexuosa), and Macaúba (Acrocomia aculeata)
}

\author{
Adriana Idalina Torcato de Oliveira, ${ }^{1}$ Talal Suleiman Mahmoud, ${ }^{2}$ \\ Guilherme Nobre L. do Nascimento, ${ }^{3}$ Juliana Fonseca Moreira da Silva, ${ }^{1}$ \\ Raphael Sanzio Pimenta, ${ }^{1}$ and Paula Benevides de Morais ${ }^{1}$ \\ ${ }^{1}$ Laboratório de Microbiologia Ambiental e Biotecnologia (LAMBIO), Universidade Federal do Tocantins, \\ 77001-923 Palmas, TO, Brazil \\ ${ }^{2}$ Centro de Estudos do Mar (CEM), Federal University of Paraná, 83255-976 Pontal do Paraná, PR, Brazil \\ ${ }^{3}$ Laboratory of Basic and Health Sciences, Federal University of Tocantins, 77001-923 Palmas, TO, Brazil
}

Correspondence should be addressed to Adriana Idalina Torcato de Oliveira; dritorcato@gmail.com

Received 19 April 2016; Revised 14 June 2016; Accepted 4 July 2016

Academic Editor: Rocio Maceiras

Copyright @ 2016 Adriana Idalina Torcato de Oliveira et al. This is an open access article distributed under the Creative Commons Attribution License, which permits unrestricted use, distribution, and reproduction in any medium, provided the original work is properly cited.

\begin{abstract}
Babaçu (A. speciosa), Buriti (M. flexuosa), and Macaúba (A. aculeata) are palm trees typical of the ecotone area between Cerrado and the Amazon rainforest. The purpose of this study was to evaluate the antimicrobial potential of the extracts prepared from the leaves of those palms as well as determine their chemical compositions. The ethanol extracts were prepared in a Soxhlet apparatus and tested by disk diffusion and agar dilution technique against Staphylococcus aureus, Enterococcus faecalis, Escherichia coli, Pseudomonas aeruginosa, Candida albicans, and Candida parapsilosis. However, there was no significant activity at concentrations of 25, 50, and $100 \mathrm{mg} \cdot \mathrm{Ml}^{-1}$. Moreover, the phytochemical analysis revealed the presence of tannins, flavonoids, catechins, steroids, triterpenes, and saponins. Gas chromatography (GC/MS) analysis also identified organic acids, such as capric (decanoic) acid, lauric (dodecanoic) acid, myristic (tetradecanoic) acid, phthalic (1,2-benzenedicarboxylic) acid, palmitic (hexadecanoic) acid, stearic (octadecanoic) acid, linoleic (9,12-octadecadienoic) acid (omega-6), linolenic (octadecatrienoic) acid (omega-3), and the terpenes citronellol and phytol. Based on the chemical composition in the palm leaf extracts, the palms have the potential to be useful in the food, cosmetic, and pharmaceutical industries.
\end{abstract}

\section{Introduction}

Brazil owns $20 \%$ of all the biodiversity in the world [1]. Unfortunately, only $10 \%$ of all plant species have been included in chemical or biological studies [2]. Generally, the therapeutic use of plants is known by conventional wisdom. However, this use should be based not only on observation but also on the results of scientific experimentation [3]. The pharmacological activity of a plant is attributable to one or more active chemical substances found in the plant tissue [4]. The phanerogams produce chemical compounds via primary and secondary metabolism. Secondary metabolites are compounds that play an important role in plant survival, providing a defense mechanism against predation by insects, herbivores, and microorganisms [5]. The Arecaceae family includes several important tropical plants, especially palm trees. Many authors consider the Arecaceae family of plants to be the most important in the life of forest people [6]. In addition, biodiversity of the palm flora of Brazil is quite rich, with an estimated 221 species [7] and 39 genera, the majority of which are found in the Amazon forest. Furthermore, in Tocantins state, it is possible to find several species of palms, including Acrocomia aculeata (Jacq.) Lodd. ex Mart. (Macaúba), Attalea speciosa Mart. ex Spreng. (Babaçu), Mauritia flexuosa L.f. (Buriti), and others [8] (Figure 1). Given the lack of scientific research on these 


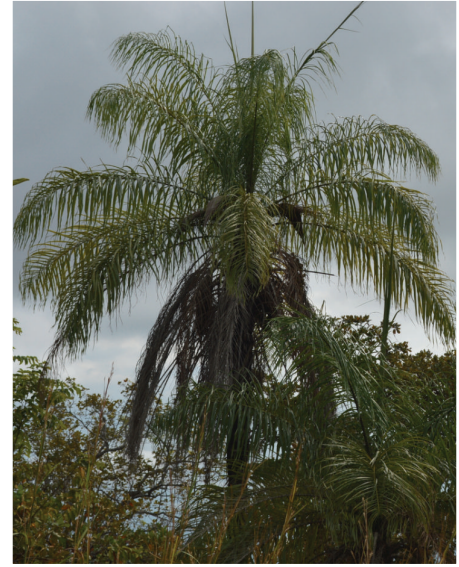

(a)

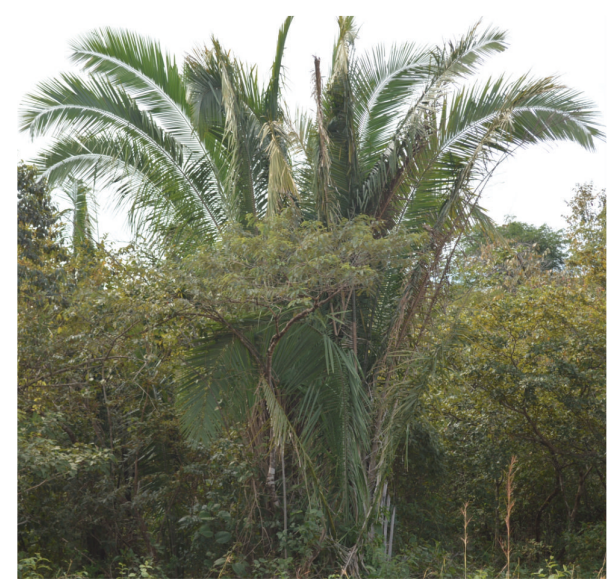

(b)

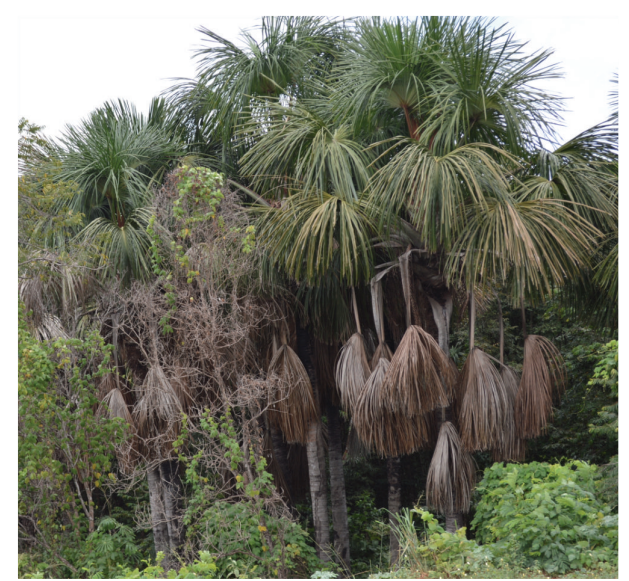

(c)

Figure 1: Photos personnel file. (a) Acrocomia aculeata. (b) Attalea speciosa. (c) Mauritia flexuosa.

palm species, this work aims to study the chemical properties and evaluate antimicrobial activity related to the ethanolic extracts obtained from their leaves.

\section{Materials and Methods}

2.1. Sample Preparation and Extraction Using Solvent. Plant samples from the palm trees A. speciosa, M. flexuosa, and A. Aculeata were made in April 2015 at Escola de Medicina Veterinária e Zootecnia, EMVZ Campus $\left(7^{\circ} 06^{\prime} 46,8^{\prime \prime} S 48^{\circ} 11^{\prime} 34\right.$, $6^{\prime \prime} \mathrm{W}$ ) of the Universidade Federal do Tocantins (UFT). Control species were located in the Herbarium HTO of UFT with the following registry numbers: Attalea speciosa (10.953), Mauritia flexuosa (10.952), and Acrocomia aculeata (10.954). In addition, dry material of the palm trees was obtained from green leaves that were cut using common scissors and dried in an oven (FANEM, São Paulo, Brazil) at $45-48^{\circ} \mathrm{C}$ for 6 hours. The moisture content of the samples was determined based on the methods of Institute Adolf Lutz [9]. The percent humidity $(U \%)$ for each species was calculated according to the following formula:

$$
U \%=\left[\frac{(\text { Green material }- \text { dry material })}{\text { green material }}\right] * 100 .
$$

The extraction of the chemical compounds was performed using a Soxhlet extractor [10]. The dry material (leaves) was weighed directly in cellulose thimbles (Babaçu: $8.595 \mathrm{~g}$, Buriti: $7.050 \mathrm{~g}$, Macaúba: $10.004 \mathrm{~g}$ ) and then was loaded into the Soxhlet. All extractions used $250 \mathrm{~mL}$ of ethanol (SigmaAldrich, Rio de Janeiro, Brazil) as the solvent, and the extraction was carried out over 5 hours with the water cooling system set to $18^{\circ} \mathrm{C}$. Ethanol is a solvent capable of extraction of a wider group of both polar and apolar compounds such as organic acids, essential oils, lipids, and pigments. It also presents a low toxicity being considered a less aggressive solvent. After extraction, the solvent was removed by rotary evaporation (CIENLAB, São Paulo, Brazil). The yield $(R \%)$ of each extract was calculated based on the amount of dry matter according to the following equation:

$$
R \%=\left[\frac{\mathrm{Mo}}{\mathrm{Bm}}-\frac{(\mathrm{Bm} \cdot \mathrm{U})}{100}\right] \cdot 100
$$

in which Mo is the mass of extract $(\mathrm{g}), \mathrm{Bm}$ is the aerial biomass (g), $U$ is the humidity, and 100 is the conversion factor for a percentage.

2.2. Phytochemical Screening. The phytochemical screening of extracts was performed in triplicate to identify secondary metabolites, such as tannins, flavonoids, catechins, carotenoids, organic acids, cardioactive glycosides, steroids and triterpenoids, saponins, sesquiterpene and other lactones, azulenes, coumarins, alkaloids, and anthraquinones [11].

2.3. Antimicrobial Activity. To evaluate the antimicrobial activity of the extracts, we used standard strains (American Type Collection Culture (ATCC)) that were obtained from the Oswaldo Cruz Foundation (Fiocruz, Rio de Janeiro, Brazil). The Gram-positive bacteria Staphylococcus aureus (ATCC 6538) and Enterococcus faecalis (ATCC 4083) and the Gram-negative bacteria Escherichia coli (ATCC 25922) and Pseudomonas aeruginosa (ATCC 27853) that are extensively used for antimicrobial tests of plant compounds were used. Additionally, Candida albicans (access number 4006) and Candida parapsilosis (access number 40038), which are leveduriformes fungi, were included in the test. The methodology was based on the disk diffusion method of Kirby-Bauer and the procedure was performed following the Performance Standards for Antimicrobial Disk Susceptibility Test [12]. The extracts were diluted in a mixture with dimethyl sulfoxide (DMSO) 10\% (Sigma-Aldrich, Rio de Janeiro, Brazil), Tween80 emulsifier 0.02\% (Synth, São Paulo, Brazil), and saline solution $0.9 \%$ [13]. The concentrations of the final solutions for each extract were $100.0 \mathrm{mg} \cdot \mathrm{mL}^{-1}, 50.0 \mathrm{mg} \cdot \mathrm{mL}^{-1}$, and $25.0 \mathrm{mg} \cdot \mathrm{mL}^{-1}$. Disks treated with $10 \%$ DMSO were used as the negative control, while the positive control disks 
TABLE 1: The major chemical compounds detected (area, \%) and retention time (RT) in the leaf extracts of $A$. speciosa, $M$. flexuosa, and $A$. aculeata by GC/MS analysis.

\begin{tabular}{|c|c|c|c|c|c|c|}
\hline \multirow{2}{*}{ Compounds } & \multicolumn{2}{|c|}{ A. speciosa } & \multicolumn{2}{|c|}{ M. flexuosa } & \multicolumn{2}{|c|}{ A. aculeata } \\
\hline & $\mathrm{RT}(\min )$ & Area\% & $\mathrm{RT}(\min )$ & Area $\%$ & $\mathrm{RT}(\min )$ & Area\% \\
\hline Capric acid, $\mathrm{C}_{11: 0}$ & 20.416 & 2.26 & 20.429 & 2.64 & nd & - \\
\hline Lauric acid, $\mathrm{C}_{12: 0}$ & nd & - & 28.925 & 1.29 & nd & - \\
\hline Myristic acid, $\mathrm{C}_{14: 0}$ & nd & - & 36.727 & 1.28 & nd & - \\
\hline Phthalic acid, $\mathrm{C}_{6} \mathrm{H}_{4}$ & nd & - & 41.883 & 1.54 & 41.866 & 1.29 \\
\hline Palmitic acid, $\mathrm{C}_{16: 0}$ & 43.927 & 3.27 & 43.861 & 20.35 & 43.816 & 12.12 \\
\hline Phytol, $\mathrm{C}_{20} \mathrm{H}_{40} \mathrm{O}$ & nd & - & 47.515 & 6.28 & 47.483 & 2.44 \\
\hline Citronellol, $\mathrm{C}_{10} \mathrm{H}_{20} \mathrm{O}$ & 48.408 & 7.65 & 48.437 & 11.75 & 48.401 & 7.63 \\
\hline Linoleic acid, $\mathrm{C}_{18: 2}(\omega 6)$ & 49.282 & 4.62 & 49.317 & 5.61 & 49.280 & 3.84 \\
\hline Linolenic acid, $\mathrm{C}_{18: 3}(\omega 3)$ & 49.515 & 20.65 & 49.540 & 19.94 & 49.501 & 18.92 \\
\hline Stearic acid, $\mathrm{C}_{18: 0}$ & 50.291 & 1.93 & 50.320 & 3.82 & 50.291 & 2.78 \\
\hline
\end{tabular}

RT: retention time in minutes; area: proportional peak area; nd: not detected.

were treated with gentamicin $(10 \mu \mathrm{g} / \mathrm{disk})$, chloramphenicol (30 $\mu \mathrm{g} /$ disk), or fluconazole (30 $\mu \mathrm{g} /$ disk). Müller-Hinton agar (bacteria) and Sabouraud Dextrose Agar (fungi) were used as growth media.

2.4. GC/MS. The chemical compounds in the plant extracts were derivatized (transesterification reaction) through acid catalysis of boron trifluoride in methanol with heat conditions according to Meher et al. (2006) [14]. The analyses were performed using a Shimadzu type GC/MS QP, 2010 Plus Model, which has a capillary column of fused silica HP-5MS $(30 \mathrm{~m} \times 0.25 \mathrm{~mm} \times 0.25 \mu \mathrm{m})$. The heating was ramped between 60 and $240^{\circ} \mathrm{C}$ at rate of $3^{\circ} \mathrm{C} / \mathrm{min}$. The injector temperature was $250^{\circ} \mathrm{C}$ in the splitless mode, and helium gas was used at a speed of $1.2 \mathrm{~mL} \cdot \mathrm{min}^{-1}$. The electron energy was $70 \mathrm{eV}$, and the temperature of the ion source was $200^{\circ} \mathrm{C}$. Finally, the identification of compounds was made by comparison of the peak mass data with the data in the NIST08 (National Institute of Standards and Technology) library.

\section{Results and Discussion}

The humidity percentage of the palm trees was $47.23 \%$ for Babaçu, 38.79\% for Buriti, and 57.93\% for Macaúba. These high humidity percentages are attributable to harvest during the rainy season. The extraction method using a Soxhlet extractor [15] resulted in a yield of $28.19 \%$ for $A$. speciosa, $33.14 \%$ for M. flexuosa, and $66.39 \%$ for A. aculeata shown in Figure 2. This is probably due to the part of the leaves used, since the extraction was made from $A$. aculeata folioles whereas in A. speciosa and M. flexuosa the whole leaf was used which included the blade with midrib and the petiole. This resulted in a drier and more powdery substrate of $A$. aculeata for the solvent to work.

The phytochemical screening of the leaf extracts from $M$. flexuosa and A. aculeata revealed the presence of tannins, flavonoids, catechins, steroids and/or triterpenoids, and saponins. However, the extract from A. speciosa revealed only flavonoids, steroids and/or triterpenoids, and saponins.

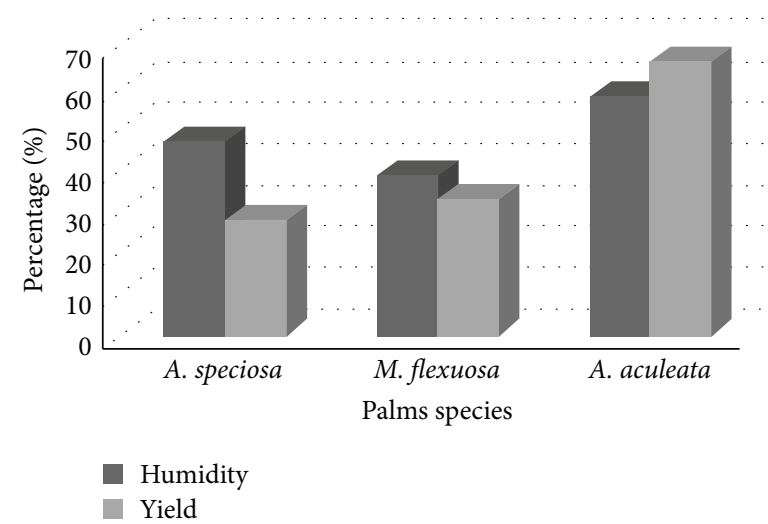

FIGURE 2: Humidity and yield extraction for A. speciosa, M. flexuosa, and $A$. aculeata.

These results indicate that the leaves of the palm trees that were studied hold promise for scientific use due to their secondary metabolites, which have biological and pharmacological activities that were found in the analysis.

The antimicrobial activity of the chemical compound found in the leaves of $A$. speciosa, M. flexuosa, and $A$. aculeata was tested against four bacterial strains and two strains of leveduriformes fungi; both are pathogens for humans and showed no sensitivity to the extracts. While the positive controls showed the expected zones of inhibition, there was no significant antimicrobial activity against the tested microorganisms based on the agar-diffusion results. The selection of microorganisms was made to verify the antimicrobial activity of the extracts. However, further tests using other strains, including plant pathogens, or the use of alternative methods should be considered.

Gas chromatography analysis of $A$. speciosa, M. flexuosa, and $A$. aculeata leaf extracts showed ten (10) chemical compounds (Table 1) that are known to have biological and pharmacological properties.

The identified compounds represent a mixture of esters derived from saturated fatty acids, unsaturated fatty acids, 
aromatics, and terpenes. The extract of $M$. flexuosa showed the highest percentage of saturated fatty acids, which are responsible for food palatability. Palmitic acid and hexadecanoic acid were found in higher concentrations in $M$. flexuosa $(20.35 \%)$ and A. aculeata (12.12\%) extracts. These fatty acids are particularly useful for improving the textural properties of foods and are used in the cosmetic industry. Moreover, the linolenic fatty acid (octadecatrienoic acid) and linoleic acid (9,12-octadecadienoic acid) are the most important finding because they are essential fatty acids (EFAs). The three analyzed palm trees showed a ratio of linolenic/linoleic acid between $4: 1$ and $5: 1$, which is the most recommended for human nutrition by leading regulatory agencies in the world, including the Scientific Review Committee (SRC) and the World Health Organization (WHO) [16]. The phytol (3,7,11,15-tetramethyl-2-hexadecen-1-ol) was found at a low concentration in both $M$. flexuosa $(6.28 \%)$ and $A$. aculeata $(2.44 \%)$ extracts and is a component of the chlorophyll molecule, which is present in green leaves of various medicinal plants and used by the cosmetic industry. The natural acyclic monoterpene citronellol is a GRAS substance (Generally Recognized as Safe for food use) and has been found in several plants reported to have antifungal, antibacterial, antispasmodic, and hypotensive properties [17]. For this reason, the presence of terpenes revealed in the phytochemical analysis were confirmed.

\section{Conclusion}

The use of ethanol has proved to be very favorable due to its low cost, its ability to be obtained by biotechnological processes, and its low toxicity [18, 19]. Although phytochemical tests did not reveal the presence of organic acids, they were verified by gas chromatography, which is a more precise method, especially when a compound is present in low concentrations. Considering this, the chemical composition of the palm tree leaves that were studied requires special consideration and attention in their interpretation. While they may vary due to environmental and/or genetic factors, this study contributes to the knowledge of the species and the expansion of its application in biotechnology. In summary, the results obtained contribute to a better understanding of the relationship between the chemical composition present in the leaves of palm trees and their scientific potential.

\section{Competing Interests}

The authors declare that there is no conflict of interests regarding the publication of this paper.

\section{Acknowledgments}

The authors express their acknowledgement to the Central Analítica of Instituto de Química (IQ) from Universidade de Brasília (UnB) for the use of its premises for GC/MS analyses and to Dr. Maria Lucilia dos Santos for support and advice.

\section{References}

[1] J. B. Calixto, "Twenty-five years of research on medicinal plants in Latin America: a personal view," Journal of Ethnopharmacology, vol. 100, no. 1-2, pp. 131-134, 2005.

[2] M. C. Pagano and M. R. Scotti, "Effect of hosphorus fertilization on arbuscular mycorrhizal colonization of Zeyheria tuberculosa a native species in Brazil's forest," Middle-East Journal of Scientific Research, vol. 6, no. 6, pp. 604-611, 2010.

[3] T. A. Aversi-Ferreira, P. P. Ribeiro, N. C. Silva et al., "Confrontation between ethnopharmacology and scientific results of the herbal medicaments from Brazil to be applied in primary health care," Journal of Medicinal Plants Research, vol. 7, no. 14, pp. 845856, 2013.

[4] R. Verpoorte, R. Van der Heijden, and J. Memelink, "Engineering the plant cell factory for secondary metabolite production," Transgenic Research, vol. 9, no. 4-5, pp. 323-343, 2000.

[5] P. J. Sixel, "Características farmacológicas gerais das plantas medicinais," Infarma, vol. 16, no. 13-14, pp. 74-77, 2005.

[6] M. A. B. Passos and M. S. Mendonça, "Epiderme dos segmentos foliares de Mauritia flexuosa L. f. (Arecaceae) em três fases de desenvolvimento," Acta Amazonica, vol. 36, no. 4, pp. 431-436, 2006.

[7] A. Henderson, G. Galeano, and R. Bernal, Field Guide to the Palms of the Americas, vol. 16, Princeton University Press, New Jersey, NJ, USA, 1996.

[8] J. F. Ribeiro and B. M. T. Walter, "As Principais Fitofisionomias do bioma Cerrado," in Cerrado: Ecologia e Flora, S. M. Sano, S. P. Almeida, and J. F. Ribeiro, Eds., pp. 151-212, Embrapa Informação Tecnológica, Brasília, Brazil, 2008.

[9] Instituto Adolfo Lutz, Normas Analíticas do Instituto Adolfo Lutz. Métodos Físico-Químicos Para Análise de Alimentos, Série A-Normas e Manuais Técnicos, Ministério da Saúde, Agência Nacional de Vigilância Sanitária, Brasília, Brazil, 4th edition, 2005.

[10] F. Soxhlet, "Die gewichtsanalytishe bestimmung des milchfettes," Polytechnisches Journal, vol. 232, no. 5, pp. 461-465, 1879.

[11] F. J. A. Matos, Introdução à Fitoquímica Experimental, Edições UFC, Fortaleza, Brazil, 2nd edition, 1997.

[12] NCCLS, Performance Standards for Antimicrobial Disk Susceptibility Tests, NCCLS Document M2-A8, NCCLS, Wayne, Pa, USA, 8th edition, 2003.

[13] F. C. Groppo, J. C. Ramacciato, R. P. Simões, F. M. Flório, and A. Sartoratto, "Antimicrobial activity of garlic, tea tree oil, and chlorhexidine against oral microorganisms," International Dental Journal, vol. 52, no. 6, pp. 433-437, 2002.

[14] L. C. Meher, D. V. Sagar, and S. N. Naik, "Technical aspects of biodiesel production by transesterification-a review," Renewable and Sustainable Energy Reviews, vol. 10, no. 3, pp. 248-268, 2006.

[15] D. T. Raspe, L. Cardozo Filho, and C. Da Silva, "Effect of additives and process variables on enzymatic hydrolysis of macauba kernel oil (Acrocomia aculeata)," International Journal of Chemical Engineering, vol. 2013, Article ID 438270, 8 pages, 2013.

[16] C. A. Martin, V. V. de Almeida, M. R. Ruiz et al., "Omega-3 and omega- 6 polyunsaturated fatty acids: importance and occurrence in foods," Revista de Nutrição, vol. 19, no. 6, pp. 761-770, 2006.

[17] J. P. Costa, N. V. Lourenço, C. C. M. P. Santos et al., "Avaliação da toxicidade aguda e das alterações histopatológicas em 
camundongos tratados com fitol," Revista de Ciências Farmacêuticas Básica e Aplicada, vol. 33, no. 3, pp. 421-428, 2012.

[18] J. F. A. Bastos, Í. J. A. Moreira, T. P. Ribeiro et al., "Hypotensive and vasorelaxant effects of citronellol, a monoterpene alcohol, in rats," Basic and Clinical Pharmacology and Toxicology, vol. 106, no. 4, pp. 331-337, 2010.

[19] A. I. T. Oliveira, G. P. Alexandre, and T. Mahmoud, "BBRbiochemistry and biotechnology reports," Biochemistry and Biotechnology Reports, vol. 2, no. 3, p. 1229, 2013. 

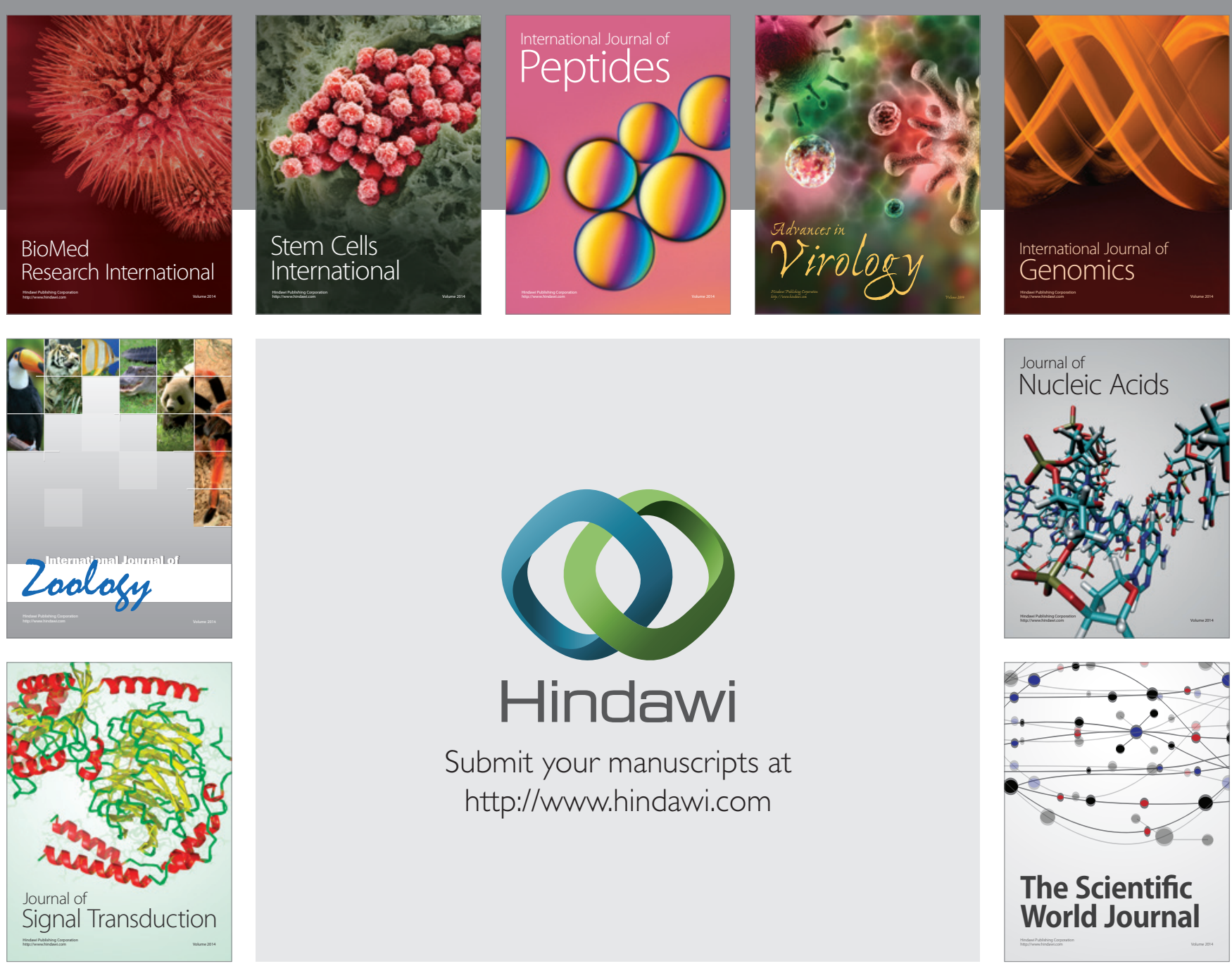

Submit your manuscripts at

http://www.hindawi.com
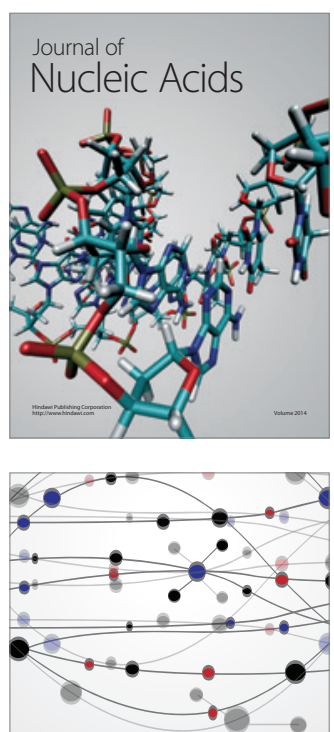

The Scientific World Journal
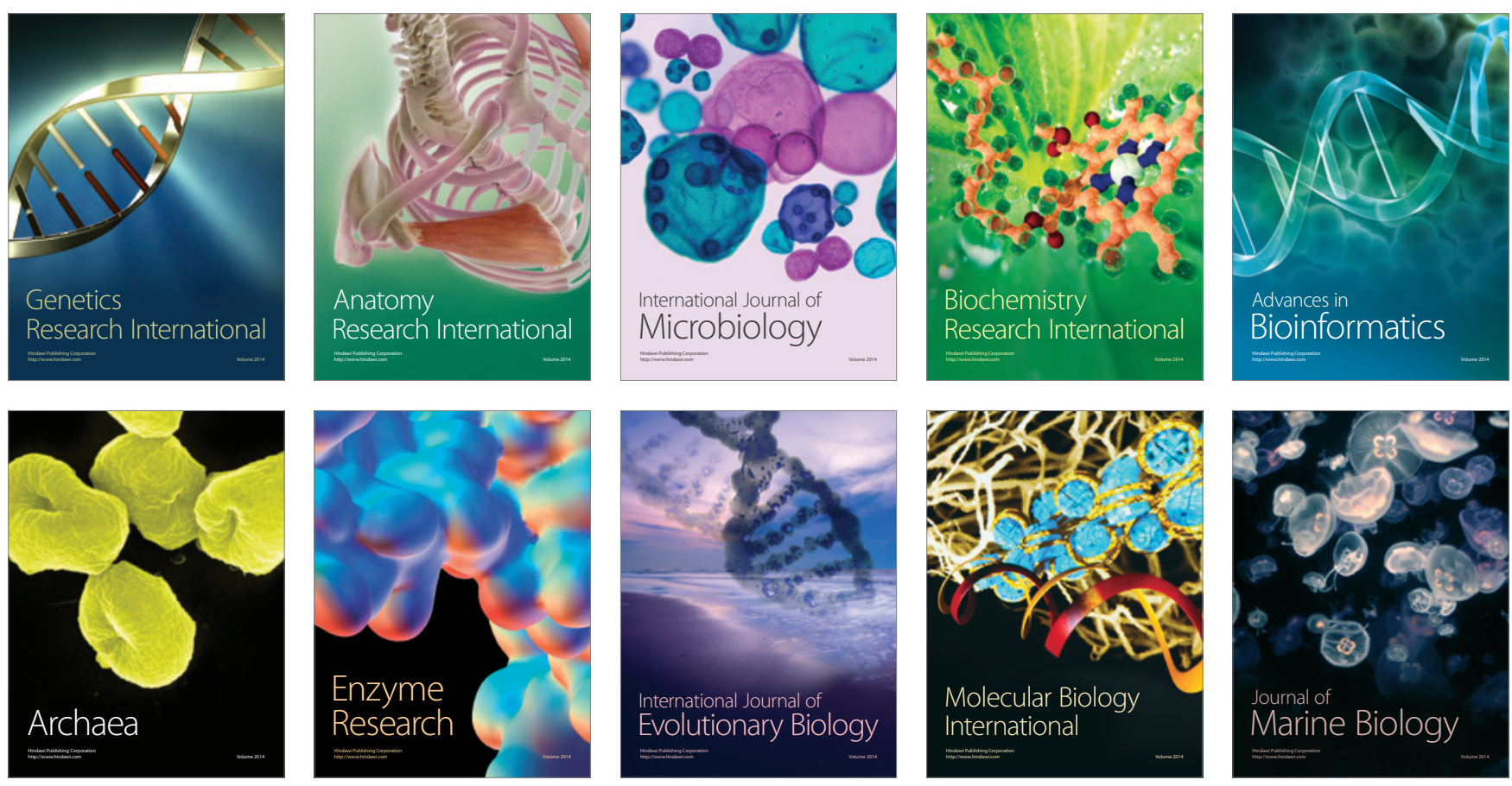